\title{
Climatic variabịlity in Mfabeni peatlands (South Africa) since the late Pleistocene
}

\section{Andrea Baker ${ }^{\mathrm{a}}$,}

beensknees@gmail.com

\section{Nikolai Pedentchouk}

\section{Joyanto Routh}

Alakendra N.

aDepartment of Earth Sciences, Stellenbosch University, Stellenbosch, South Africa

${ }^{\mathbf{b}}$ School of Environmental Sciences, University of East Anglia, Norwich, UK

${ }^{\mathbf{c}}$ Department of Thematic Studies - Environmental Change, Linköping University, Linköping, Sweden

*Corresponding author. Department of Earth Sciences, Stellenbosch University, Private Bag X1, Matieland, 7602, South Africa.

\section{Abstract}

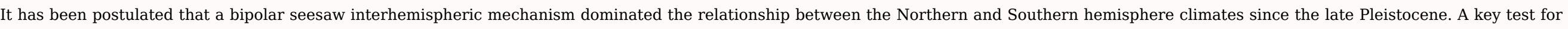

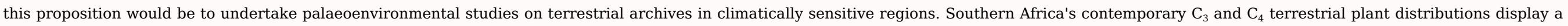

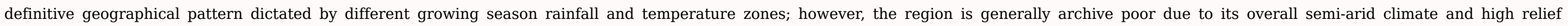

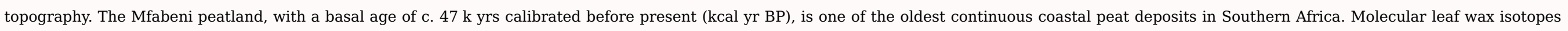

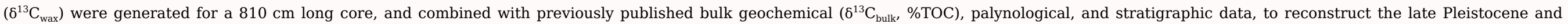

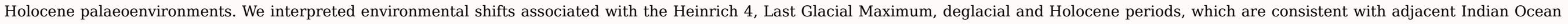

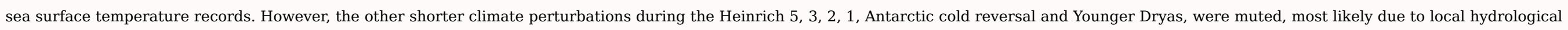

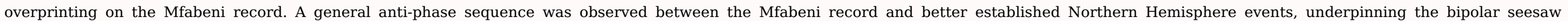
interhemispheric mechanism proposed for global climate forcing since the Late Pleistocene.

Keywords: Holocene; Pleistocene; Paleoclimatology; Southern Africa; Stable isotopes; Continental biomarkers; Peatland

\section{Introduction}

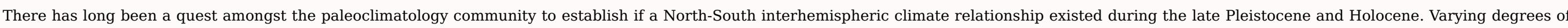

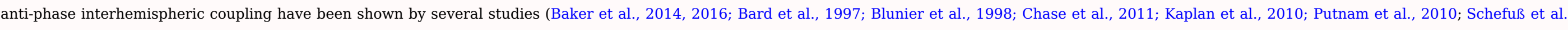

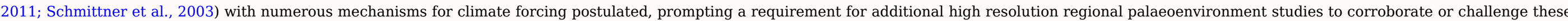

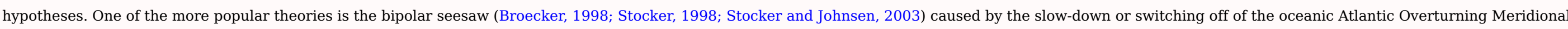

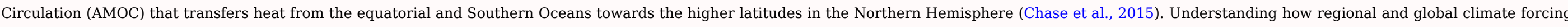

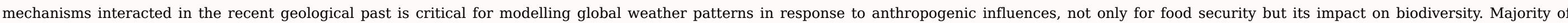

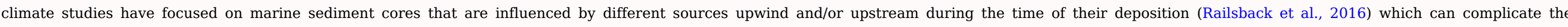

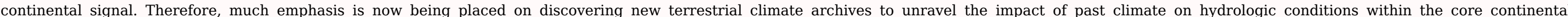




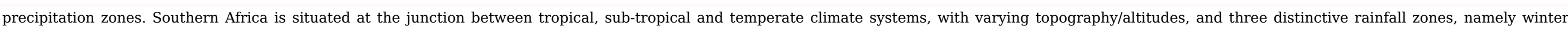

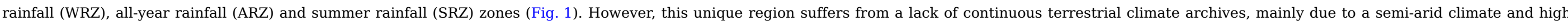

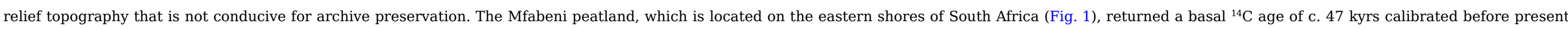

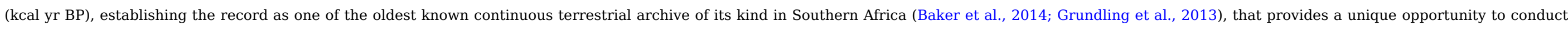
high-resolution glacial and interglacial palaeoecological investigations of past climate in Southeast Africa.

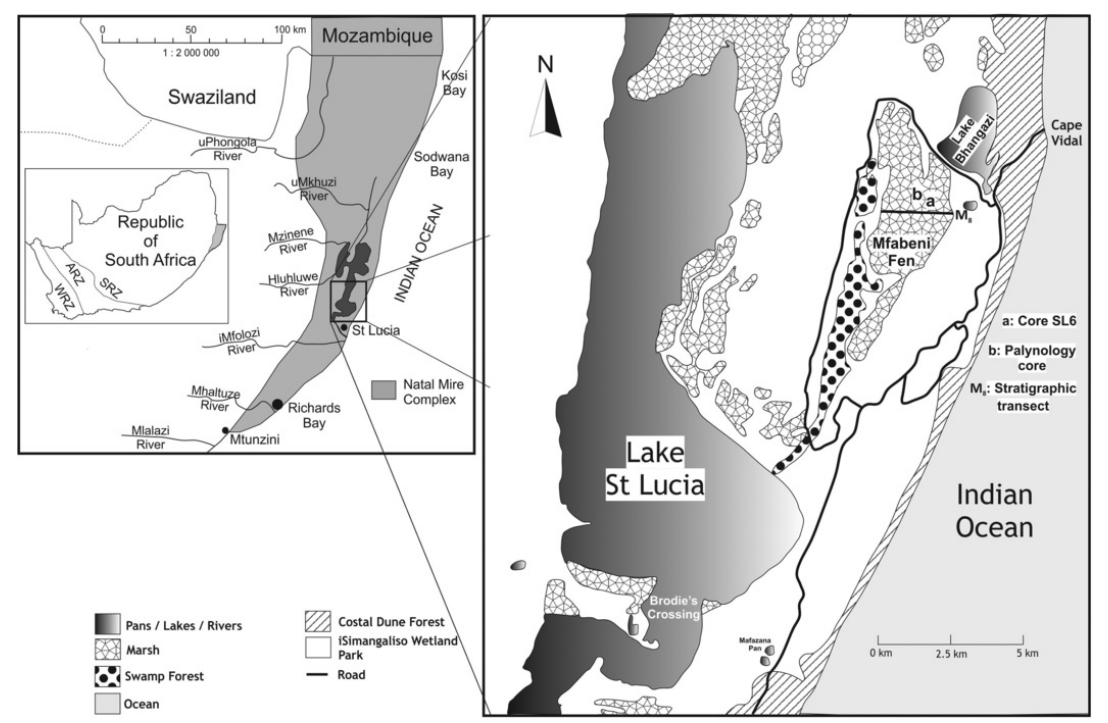

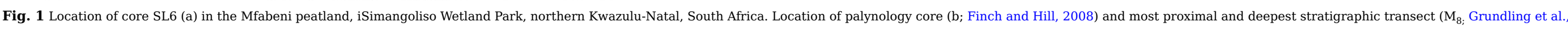
2013) included for orientation. $\mathrm{WRZ}=$ winter rainfall zone; ARZ = all-year rainfall zone; SRZ = summer rainfall zone. Modified from Baker et al. (2016).

\section{alt-text: Fig. 1}

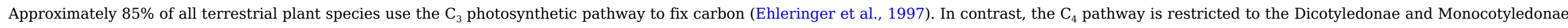

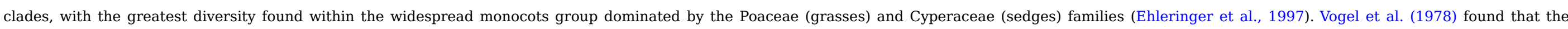

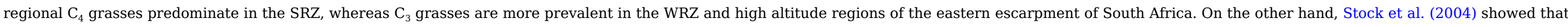

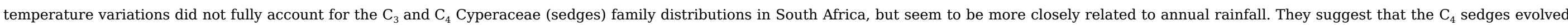

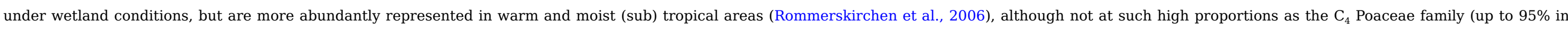
SRZ; Vogel et al., 1978).

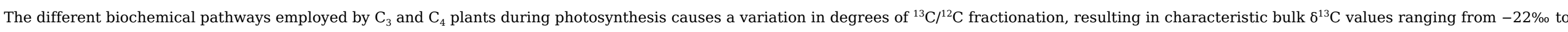

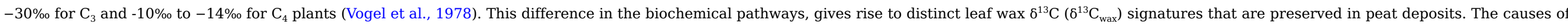

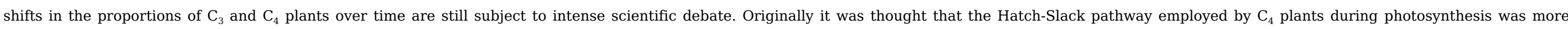

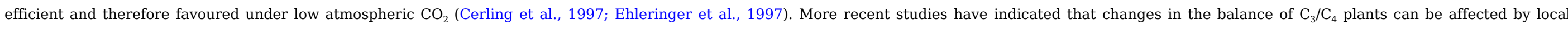

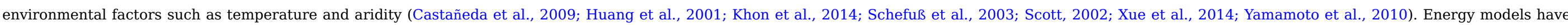

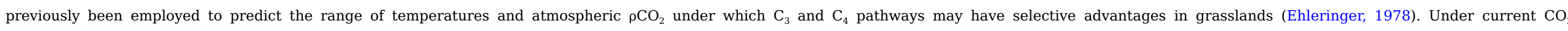

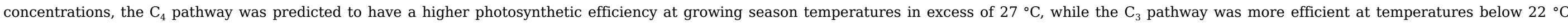

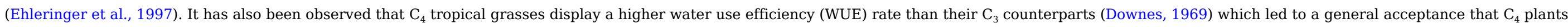




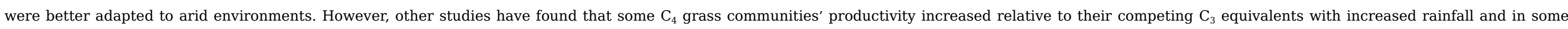

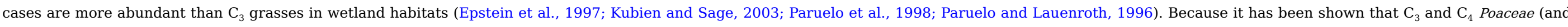

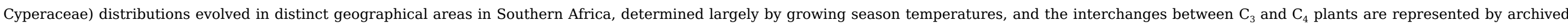

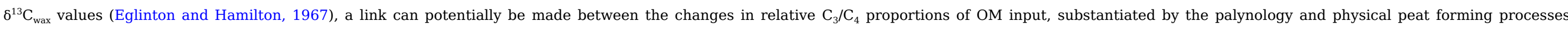
archived in the Mfabeni peat deposit, and fluctuations in palaeotemperature and paleohydrology at the time of sedimentation.

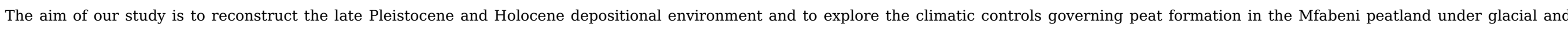

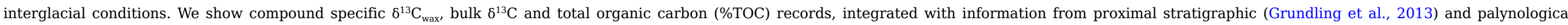

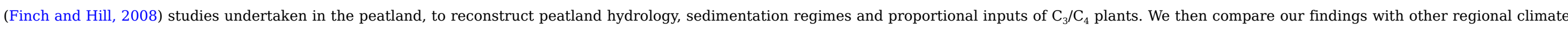

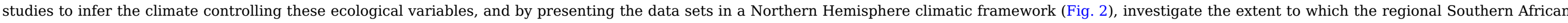
climatic signals correlate with global climatic events since the Late Pleistocene.

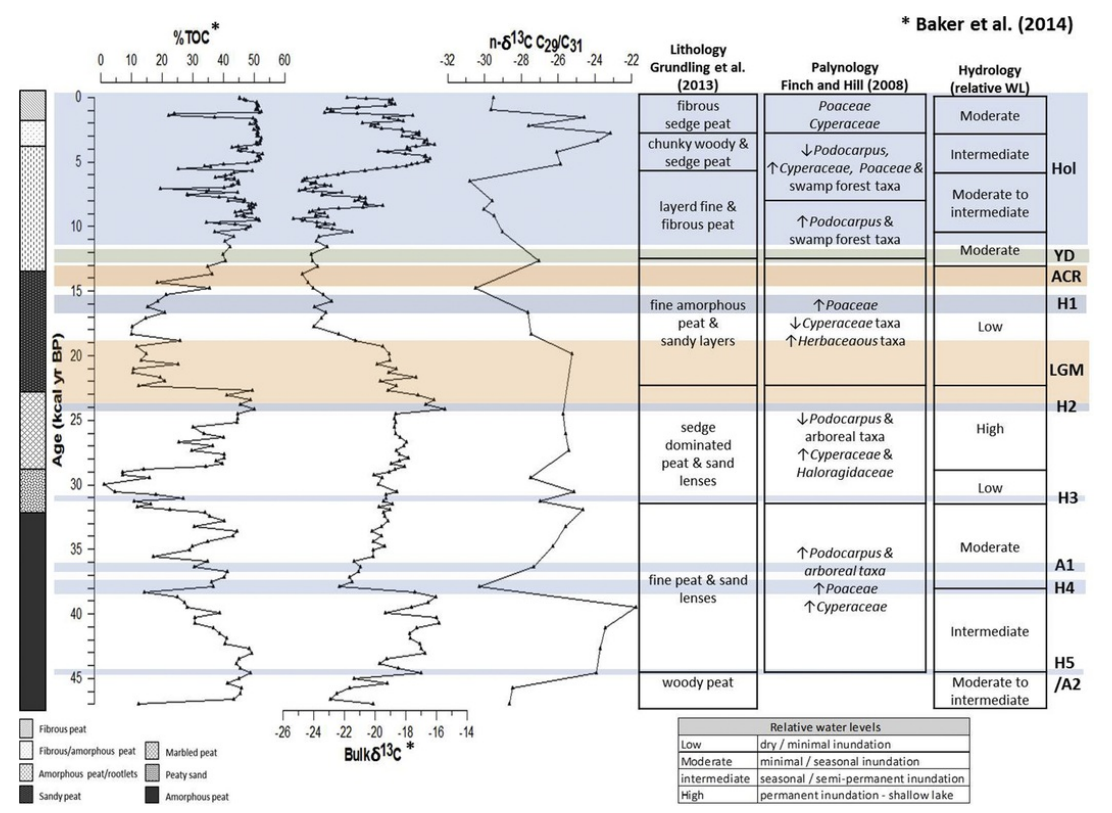

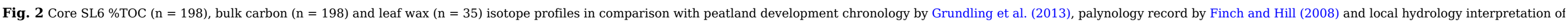

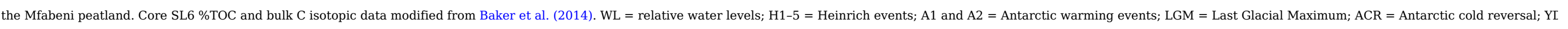
= Younger Dryas; $\mathrm{Hol}=$ Holocene.

alt-text: Fig. 2

\section{Methods}

\subsection{Site description}

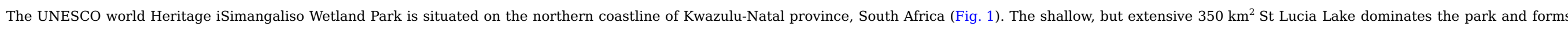

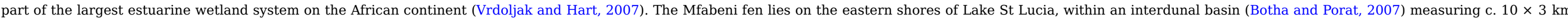

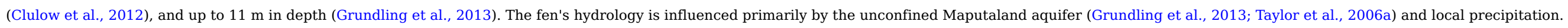




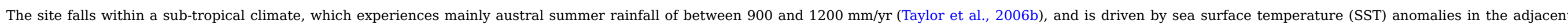

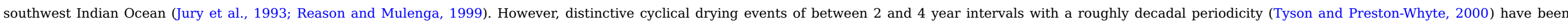

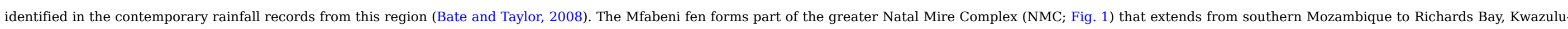

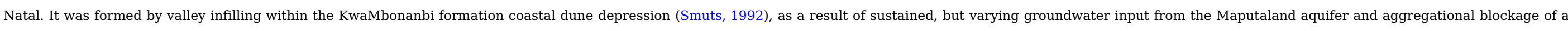

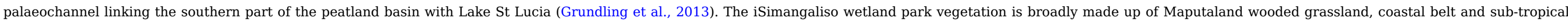
freshwater wetland and northern coastal forests (Mucina et al., 2006), whereas the fen itself is dominated by herbaceous reed sedges and grasses (Finch and Hill, 2008).

\subsection{Sampling}

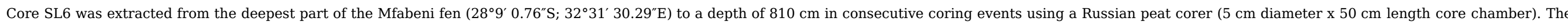

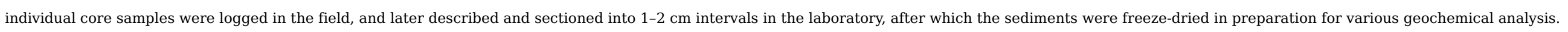

\subsection{Radiocarbon dating}

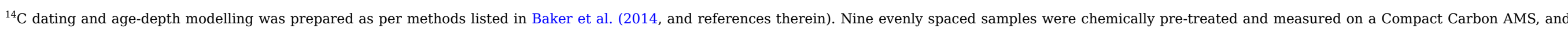

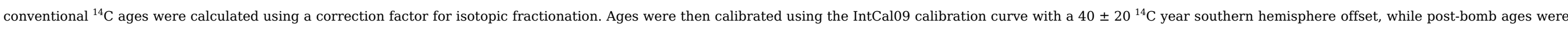
calibrated using the southern hemisphere post-bomb curve. Comprehensive core ages were extrapolated within the Bayesian framework, using the age-depth Bacon modelling software.

\subsection{Bulk stable $C$ isotope analyses}

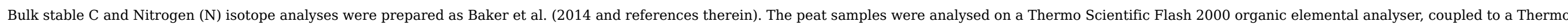

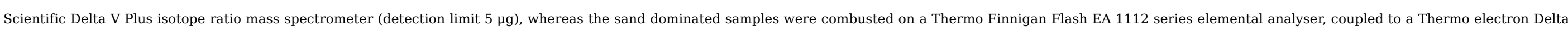

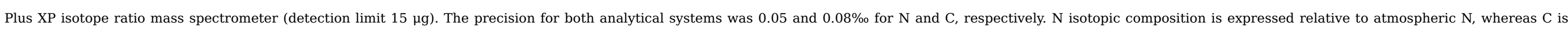
expressed relative to the Vienna Pee-Dee Belemnite.

\subsection{Compound specific $n$-alkane leaf wax isotope analyses}

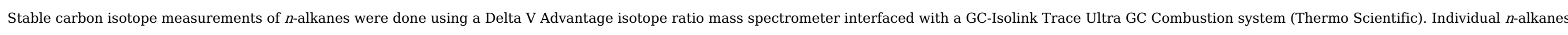

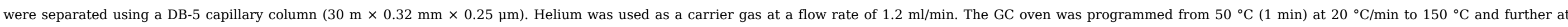

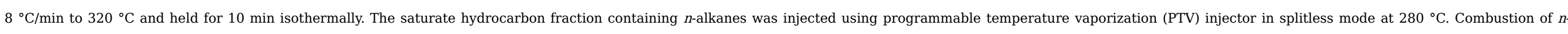

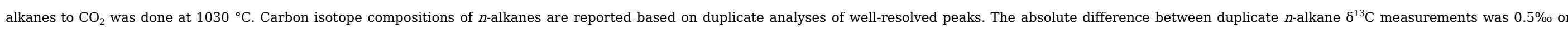
better.

The weighted average for the $8^{13} \mathrm{C}$ values of $n-\mathrm{C}_{29}$ and $n-\mathrm{C}_{31}$ alkanes was determined using the following equation:

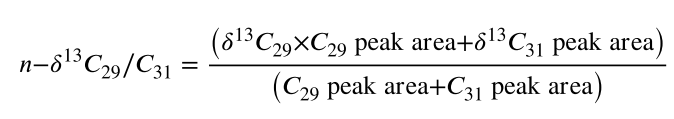

\section{Results}

\subsection{Leaf wax $6^{13} \mathrm{C}$ signatures $\left(6^{13} \mathrm{C}_{\text {wax }}\right)$}

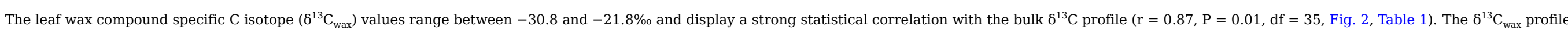

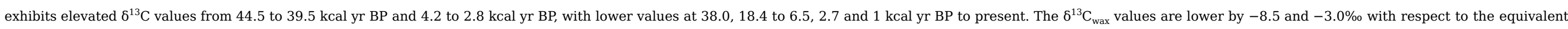
bulk $\delta^{13} \mathrm{C}$ (Table 1 ).

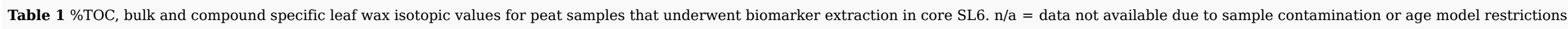




\section{alt-text: Table 1}

Depth (cm)

Age kcal yr BP

TOC $\mathrm{m}-2 \mathrm{gC} \mathrm{m}-2$

Bulk $\delta^{13} \mathrm{C}$

CSIA $\delta^{13} C^{29 /} C^{31}$

8

42

57

75

93

108

135

158

192

209

237

258

273

310

335

355

375

390

405

424

450

470

490

510

539

555

580

595

610

630
$-0.02$

0.98

1.54

2.17

2.81

3.39

4.26

5.14

6.46

7.08

7.99

8.69

9.17

10.40

12.64

14.79

16.67

18.32

19.83

21.34

23.06

24.50

26.07

27.33

28.77

29.46

30.58

31.24

31.90

33.21 n/a

1163

540

1121

1370

1491

1311

1146

1227

371

1194

1401

1001

729

1005

871

657

295

469

393

1131

1118

955

850

434

510

157

371

671

900
$-21.8$

$-22.9$

$-19.5$

$-20.3$

$-17.3$

$-16.8$

$-19.2$

$-17.6$

$-24.8$

$-24.5$

$-21.3$

$-23.7$

$-23.9$

$-21.5$

$-24.1$

$-24.0$

$-23.2$

$-22.4$

$-19.1$

$-19.1$

$-17.2$

$-18.7$

$-18.7$

$-18.6$

$-18.7$

$-19.5$

$-18.6$

$-19.5$

$-19.0$

$-19.6$
$-29.5$

$-29.7$

$-24.6$

$-27.6$

$-23.2$

$-23.8$

$-26.1$

$-25.9$

$-30.8$

n/a

$-29.6$

$-30.0$

$-29.5$

$-29.1$

$-27.1$

$-30.5$

$-27.6$

$-27.5$

$-25.3$

n/a

n/a

$-25.7$

$-25.6$

$-25.4$

n/a

$-27.5$

$-25.2$

$-27.0$

$-24.6$

$-25.6$ 


\begin{tabular}{|c|c|c|c|c|}
\hline 650 & 34.76 & 810 & -19.3 & -26.3 \\
\hline 670 & 36.33 & 821 & -21.0 & -27.3 \\
\hline 690 & 37.92 & 1063 & -22.3 & -30.3 \\
\hline 710 & 39.52 & 922 & -17.6 & -21.8 \\
\hline 730 & 41.10 & 1080 & -17.3 & -23.4 \\
\hline 750 & 42.68 & 1251 & -17.0 & -23.7 \\
\hline 775 & 44.61 & 1602 & -17.0 & -23.9 \\
\hline 790 & 45.78 & 1441 & -21.7 & -28.5 \\
\hline 805 & 46.97 & 396 & -20.1 & -28.7 \\
\hline
\end{tabular}

\subsection{Bulk $\delta^{13} \mathrm{C}$ signatures $\left(\delta^{13} \mathrm{C}_{\text {bulk }}\right)$}

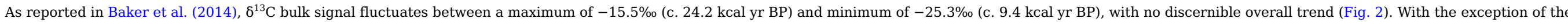

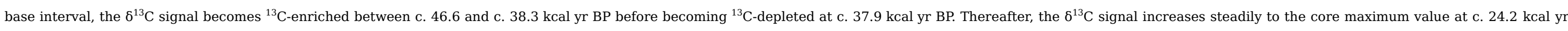

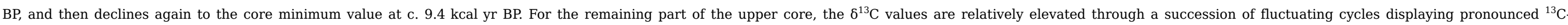
enrichment shifts by $4.5 \%$ (c. 8.8 to $8.4 \mathrm{kcal} \mathrm{yr} \mathrm{BP),} 8.2 \%$ (c. 6.5 to $4.7 \mathrm{kcal} \mathrm{yr} \mathrm{BP),} \mathrm{and} 4.5 \%$ (c. 1.2 to $0.15 \mathrm{kcal} \mathrm{yr} \mathrm{BP).}$

\subsection{Total organic carbon (\%TOC)}

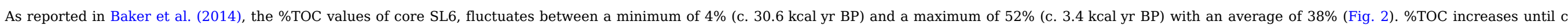

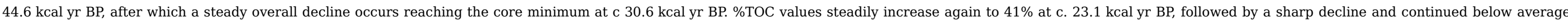

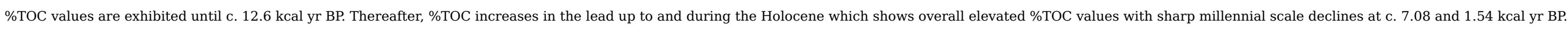

\section{Discussion}

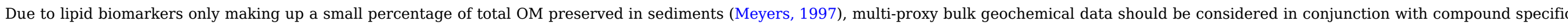

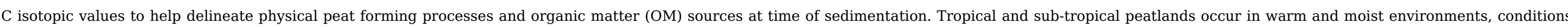

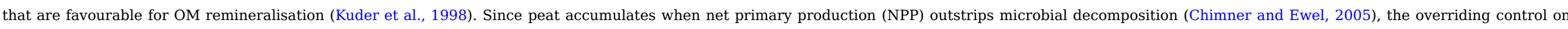

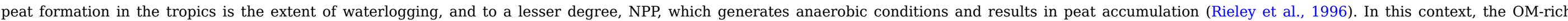

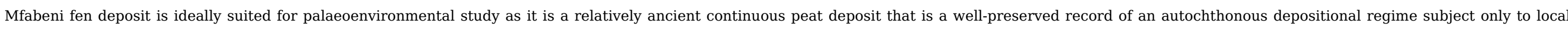
precipitation and groundwater recharge (Baker et al., 2014; Grundling et al., 2013).

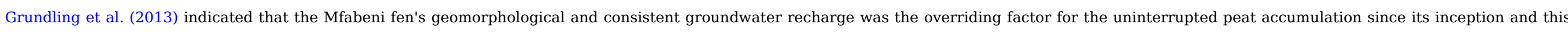

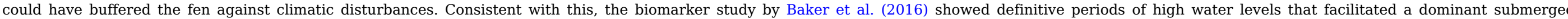

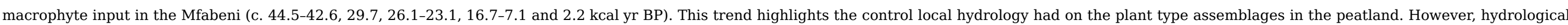

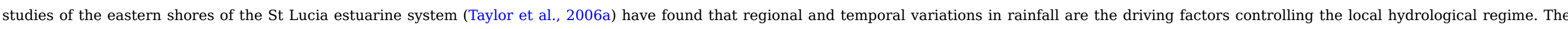

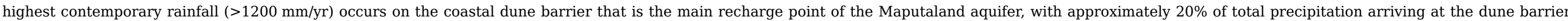
entering the aquifer (Kelbe and Rawlins, 1993).

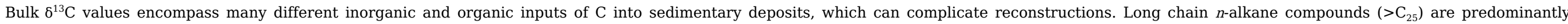

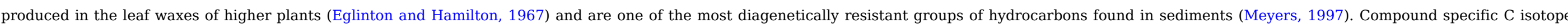




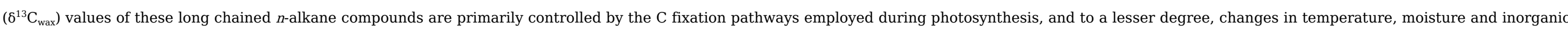

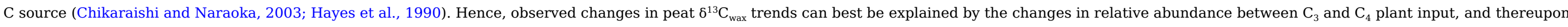

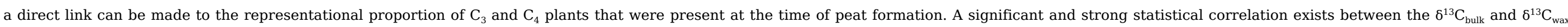

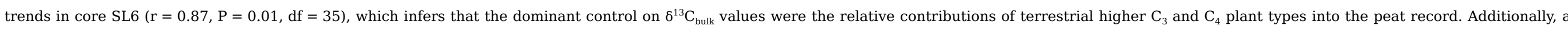

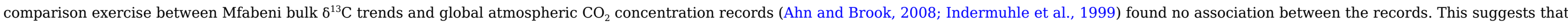
changes in atmospheric $\rho \mathrm{CO}_{2}$ were not a major cause for shifts in the proportion of $\mathrm{C}_{3}$ and $\mathrm{C}_{4}$ plants at the site through time.

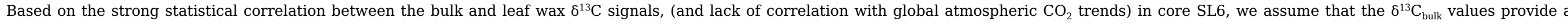

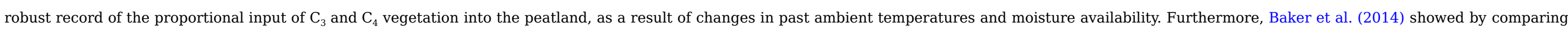

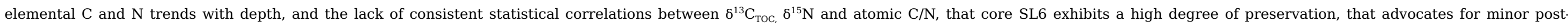
depositional isotopic $\mathrm{C}$ fractionation in the Mfabeni peatland.

\subsection{Plant assemblage and chronology}

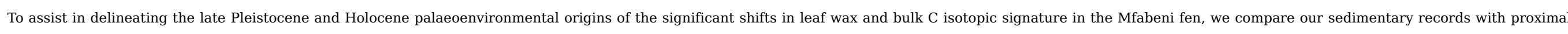

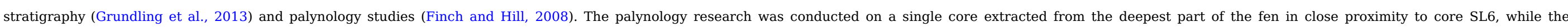

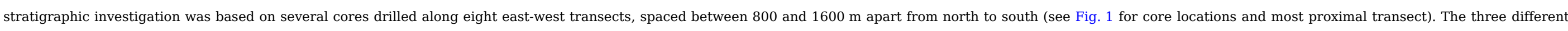

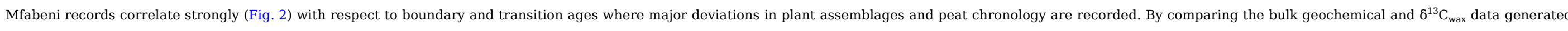
from core SL6, with the proximal stratigraphic and palynology records, we were able to reconstruct the palaeoenvironmental changes in the Mfabeni peatland since 47 kcal yr BP.

\subsubsection{Before the Last Glacial Maximum (LGM)}

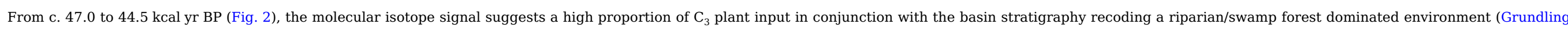

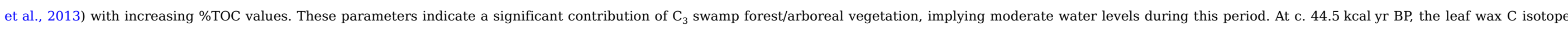

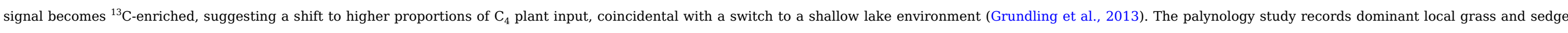

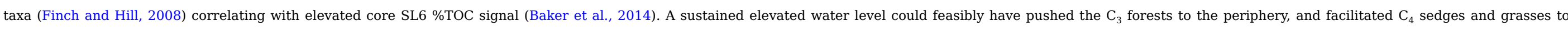

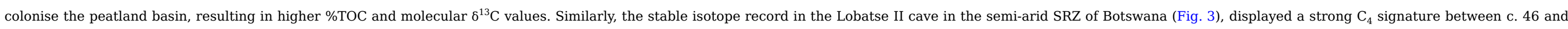
$43 \mathrm{kyr} \mathrm{BP}$, which Holmgren et al. (1995) proposed was as a result of $\mathrm{C}_{4}$ grass proliferation in response to a drier climate, rather than a reduction of winter precipitation. 


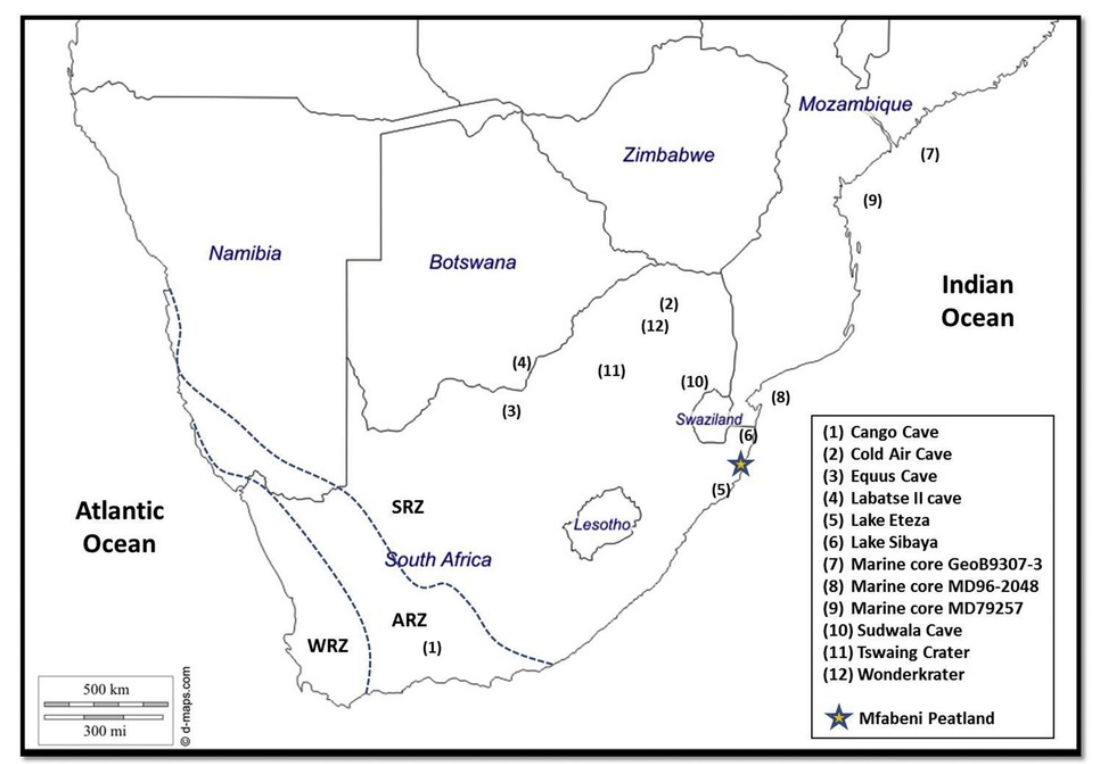

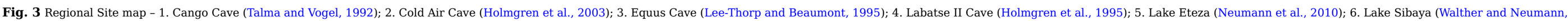

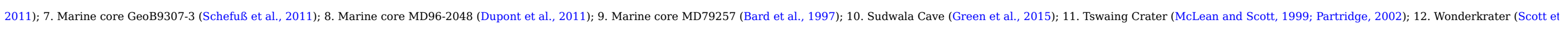
al., 2003; Truc et al., 2013). WRZ = winter rainfall zone; ARZ = all-year rainfall zone; SRZ = summer rainfall zone

\section{alt-text: Fig. 3}

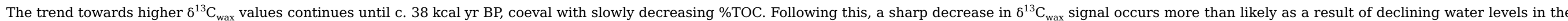

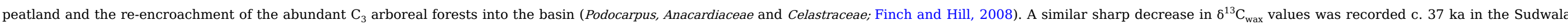

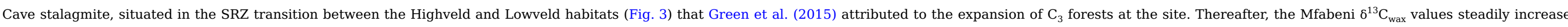

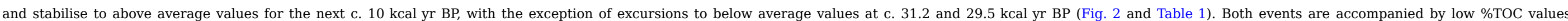

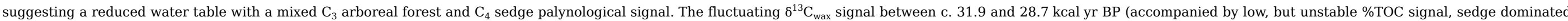

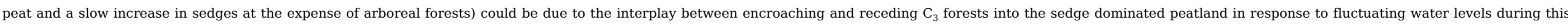

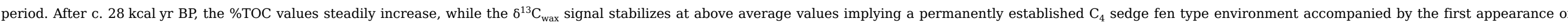

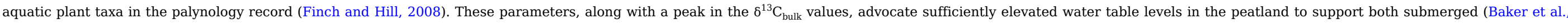
2016) and emergent plant types to the exclusion of arboreal forests up until c. 23 kcal yr BP.

\subsubsection{The Last Glacial Maximum and deglacial}

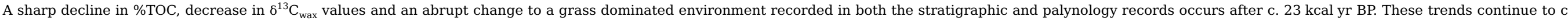

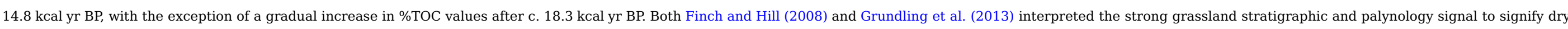

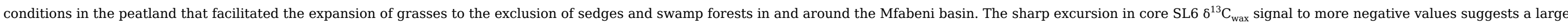

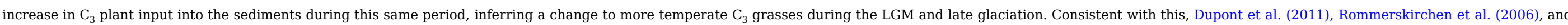

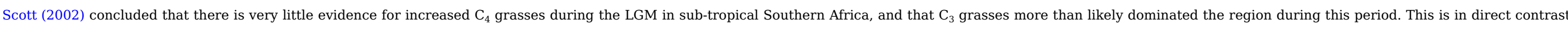

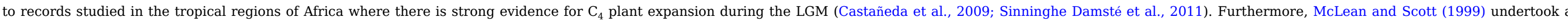

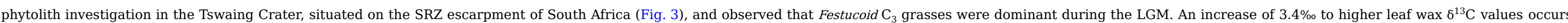




\subsubsection{Holocene}

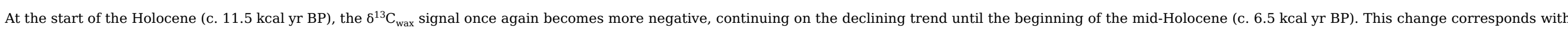

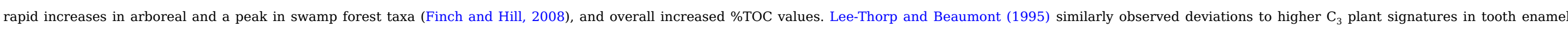

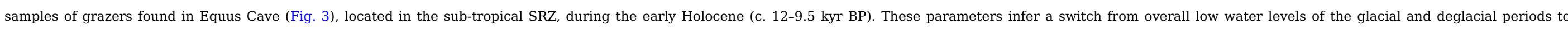

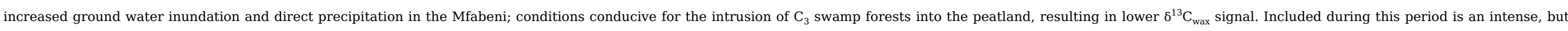

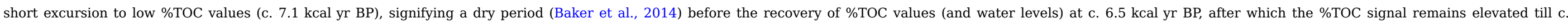

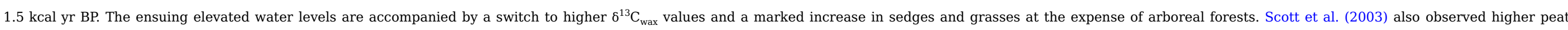

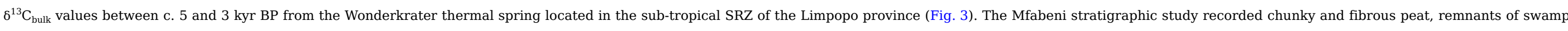

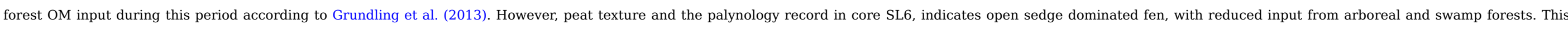

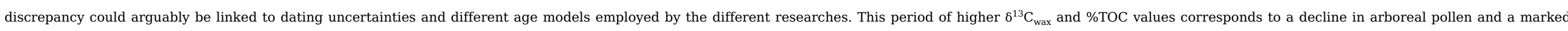

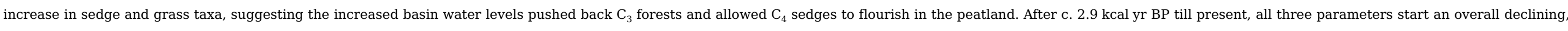

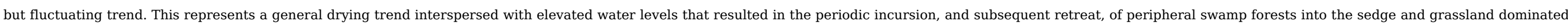
peat, as is prevalent in the plant distribution found in and around the peatland today.

\subsection{Palaeoclimate reconstruction}

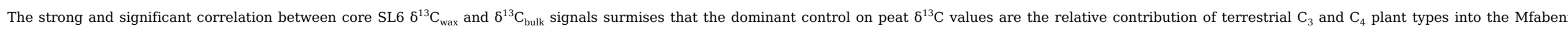

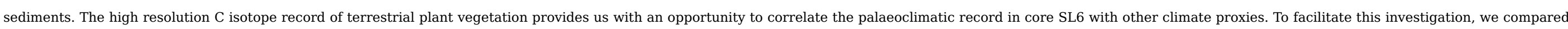

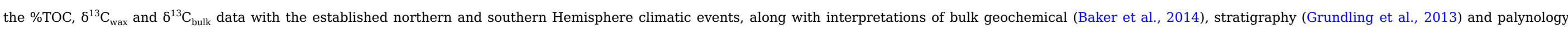
(Finch and Hill, 2008) investigations in the Mfabeni deposit (Fig. 2).

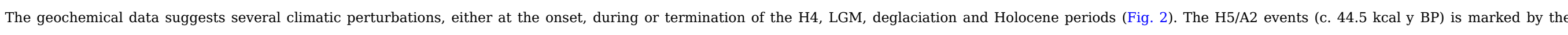

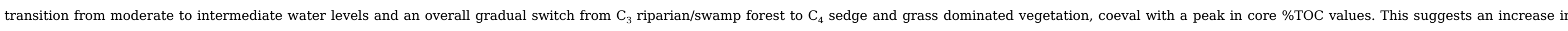

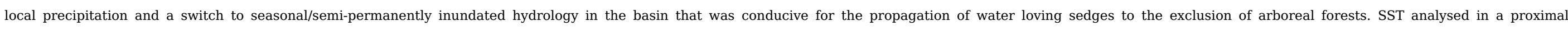

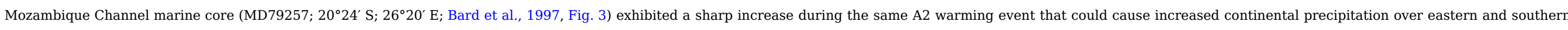
Africa (Dupont et al., 2011; Goddard and Graham, 1999).

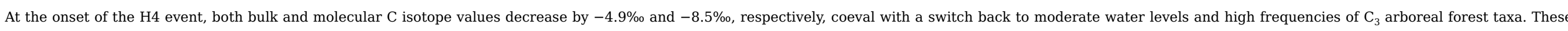

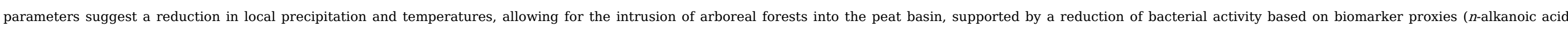

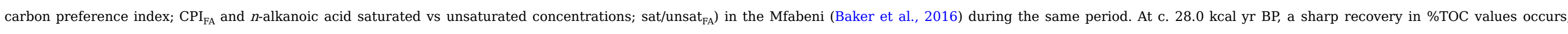

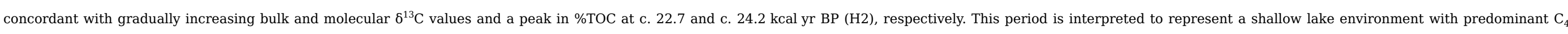

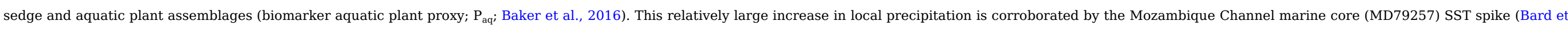

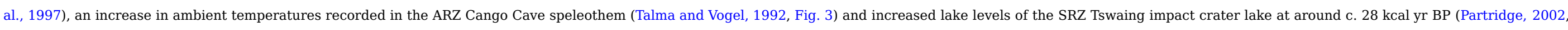
Fig. 3).

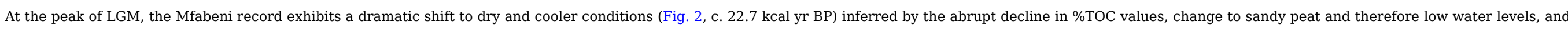

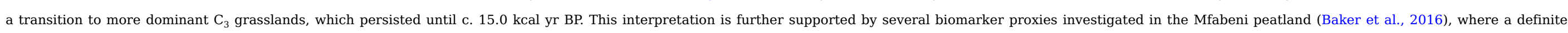

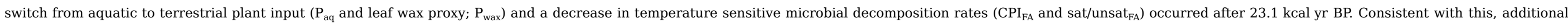




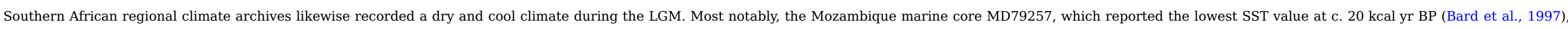

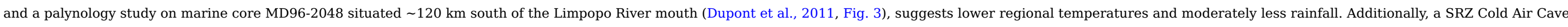

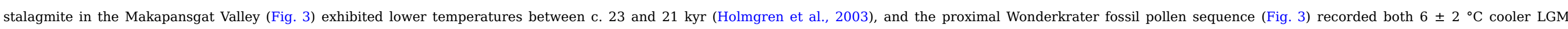

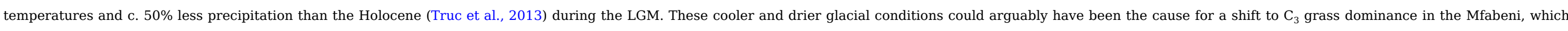

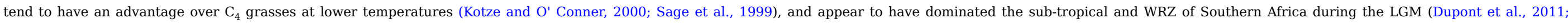

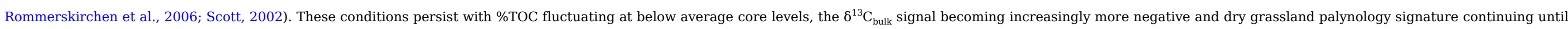

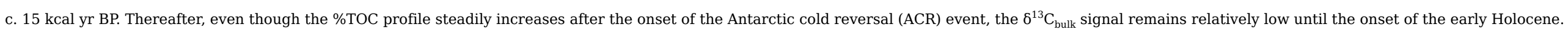

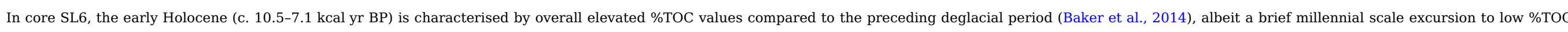

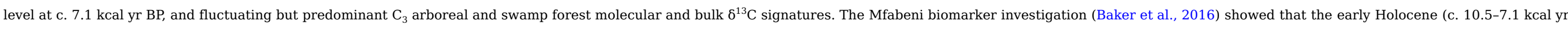

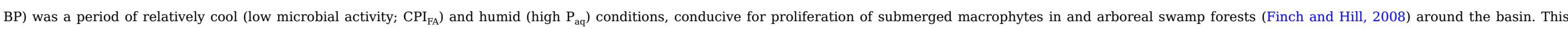
interpretation is supported by the Wonderkrater palynology sequence (Truc et al., 2013) and stable isotope speleothem record in the Cold Air Cave (Holmgren et al., 2003).

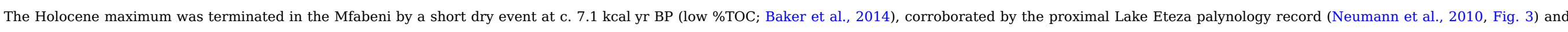

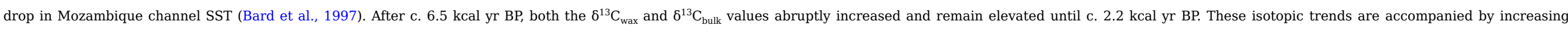

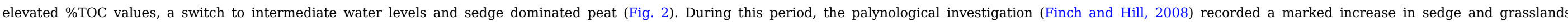

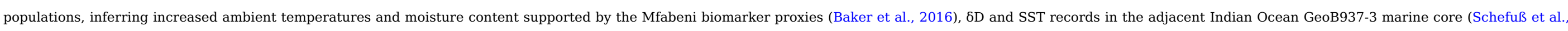

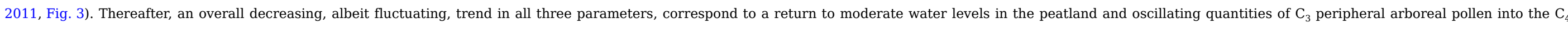

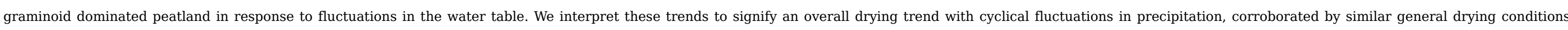

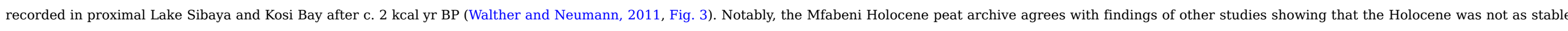
as previously perceived both regionally (Baker et al., 2014; Bard et al., 1997; Schefuß et al., 2011) and globally (Mayewski et al., 2004).

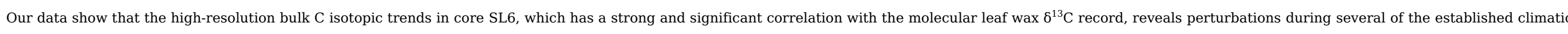

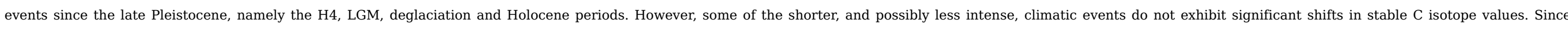

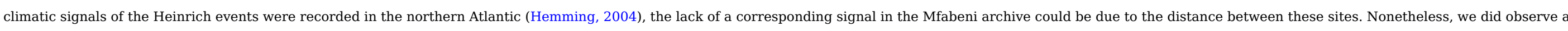

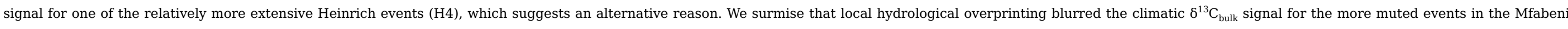

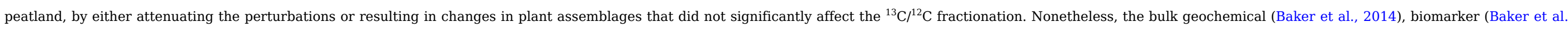

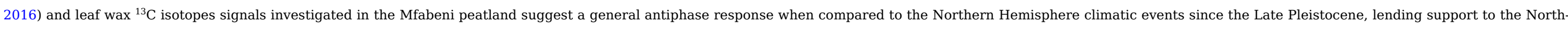
South interhemispheric seesaw hypothesis.

\section{Conclusions}

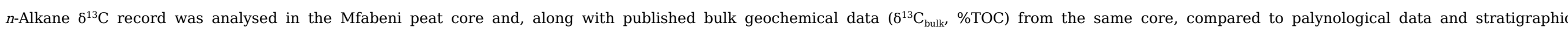

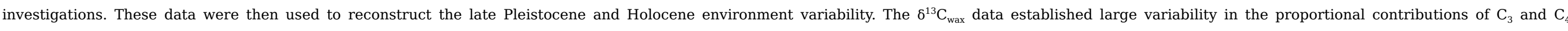

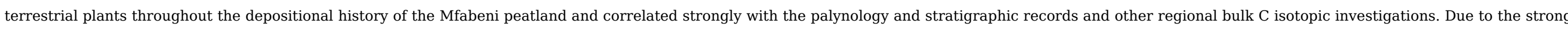

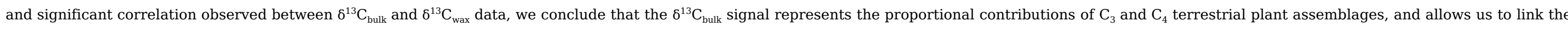

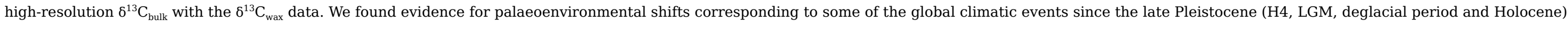

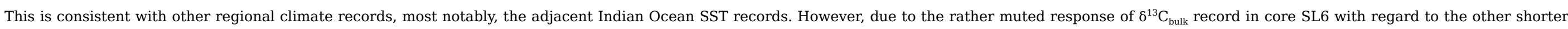

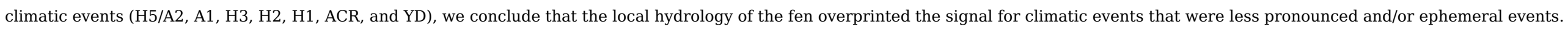

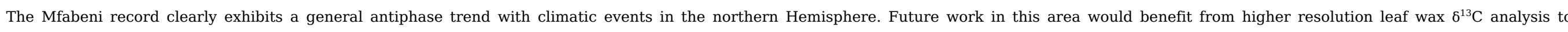

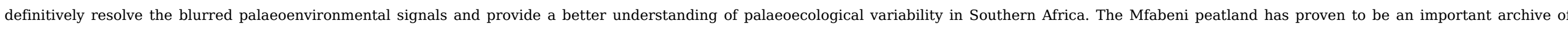




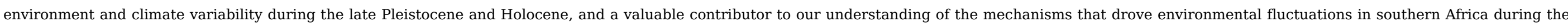
last glacial and interglacial periods.

\section{Acknowledgments}

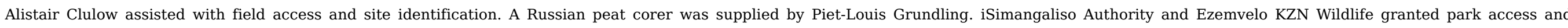

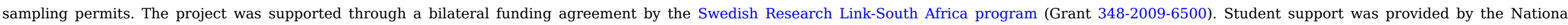
Research Foundation and InKaba yeAfrica. This is an Inkaba ye Africa publication no. 160 and AEON publication no. 153.

\section{References}

Ahn J. and Brook E.J., Atmospheric CO2 and climate on millennial time scales during the last glacial period, Science 322, $2008,83-85$.

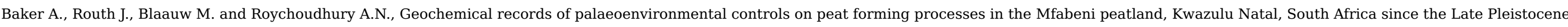
Palaeogeogr. Palaeoclimatol. Palaeoecol. 395, 2014, 95-106.

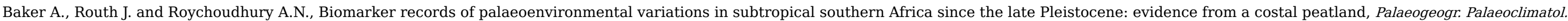
Palaeoecol. 451, 2016, 1-12.

Bard E., Rostek F. and Sonzogni C., Interhemispheric synchrony of the last deglaciation inferred from alkenone palaeothermometry, Nature 385, 1997, 707-710.

Bate G.C. and Taylor R.H., Sediment salt-load in the St Lucia estuary during the severe drought of 2002-2006, Environ. Geol. 55, 2008, 1089-1098.

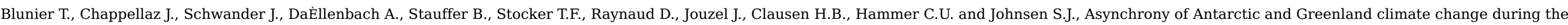
last glacial period, Nature 394, 1998, 739-743.

Botha G. and Porat N., Soil chronosequence development in dunes on the southeast African coastal plain, Maputaland, South Africa, Quat. Int. 162-163, 2007, 111-132.

Broecker W.S., Paleocean circulation during the last deglaciation: a bipolar seesaw?, Paleoceanography 13, 1998, 119-121.

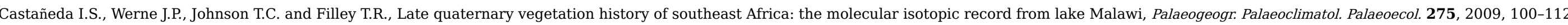

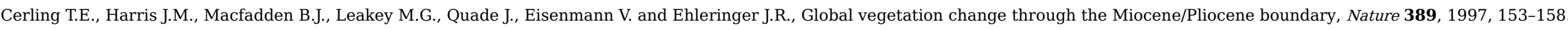

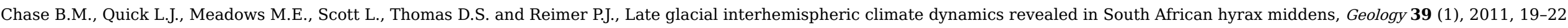

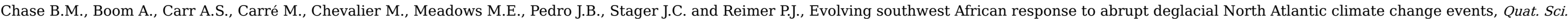
Rev. 121, 2015, 132-136, http://dx.doi.org/10.1016/j.quascirev.2015.05.023.

Chikaraishi Y. and Naraoka H., Compound-specific 6D-613C analyses of n-alkanes extracted from terrestrial and aquatic plants, Phytochemistry 63, 2003, 361-371.

Chimner R.A. and Ewel K.C., A tropical freshwater wetland: II. Production, decomposition, and peat formation, Wetl. Ecol. Manag. 13, 2005, 671-684.

Downes R.W., Differences in transpiration rates between tropical and temporate grasses under controlled conditions, Planta 88, 1969, 261-273.

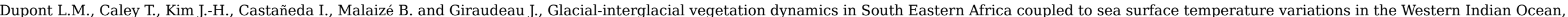
Clim. Past. 7, 2011, 1209-1224.

Eglinton G. and Hamilton R.J., Leaf epicuticular waxes, Science 156, 1967, 1322-1335.

Ehleringer J.R., Implications of quantum yield differences on the distribution of C3 and C4 grasses, Oecologia 31, 1978, 255-267.

Ehleringer J.R., Cerling T.E. and Helliker B.R., C4 Photosynthesis, atmospheric CO2 and climate, Oecologia 112, 1997, $285-299$. 
Epstein H.E., Lauenroth W.K., Burke I.C. and Coffin D.P., Productivity patterns of C3 and C4 functional types in the U.S. Great plains, Ecology 78, 1997 , 722-731.

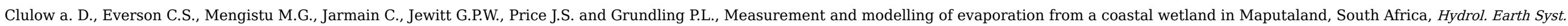
Sci. 16, 2012, 3233-3247.

Finch J.M. and Hill T.R., A late Quaternary pollen sequence from Mfabeni Peatland, South Africa: reconstructing forest history in Maputaland, Quat. Res. 70, $2008,442-450$.

Goddard L. and Graham N.E., Importance of the Indian Ocean for simulating rainfall anomalies over eastern and Southern Africa, J. Geophys. Res. 104, 1999, 190-199.

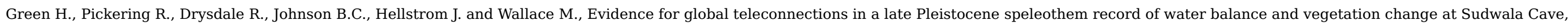
South Africa, Quat. Sci. Rev. 110, 2015, 114-130.

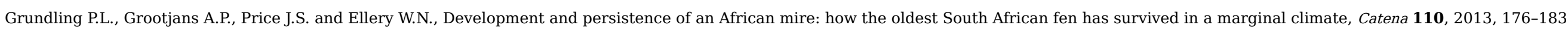

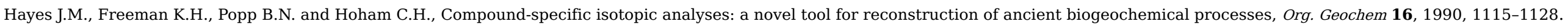

Hemming S.R., Heinrich events: massive late Pleistocene detritus layers of the North Atlantic and their global climate imprint, Rev. Geophys. 42 (1), $2004,1-43$.

Holmgren K., Karlén W. and Shaw P.A., Paleoclimatic significance of the stable isotopic composition and petrology of a late pleistocene stalagmite from Botswana, Quat. Res. 43, 1995, 320-328.

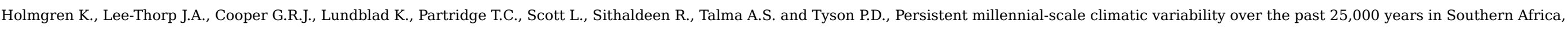
Quat. Sci. Rev. 22, 2003, 2311-2326.

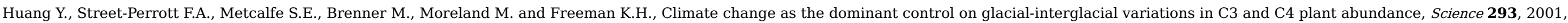
1647-1651.

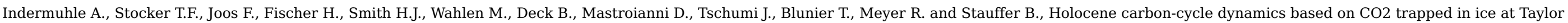
Dome, Antarctica, Nature 398, 1999, 121-126.

Jury M.R., Valentine H.R. and Lutjeharms J.R.E., Influence of the agulhas current on summer rainfall along the southeast coast of South Africa, J. Appl. Meteorol. 32, 1993, 1282-1287.

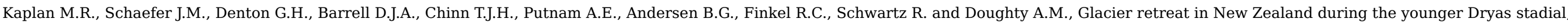
Nature 467 (7312), 2010, 194-197.

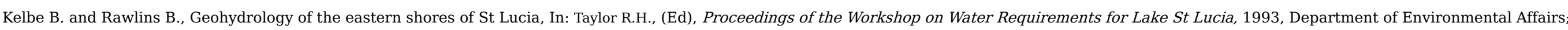
Pretoria, South Africa, 32-38.

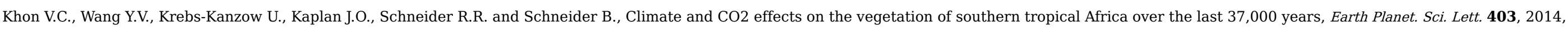
407-417.

Kotze D.C. and O' Connor T.G., Vegetation variation within and among palustrine wetlands along an altitudinal gradient in KwaZulu-Natal, South Africa, Plant Ecol. 146, $2000,77-96$.

Kubien D.S. and Sage R.F., C4 grasses in boreal fens: their occurrence in relation to microsite characteristics, Oecologia 137, 2003, 330-337.

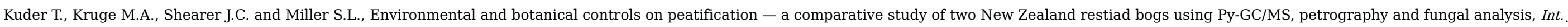
Coal Geol. 37, 1998, 3-27.

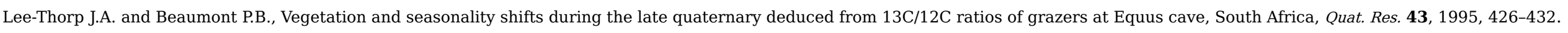

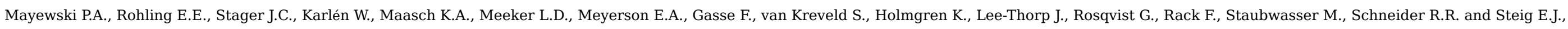
Holocene climate variability, Quat. Res. 62, 2004, 243-255. 


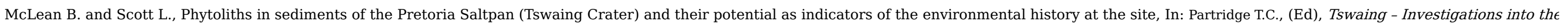

Origin, Age and Palaeoenvironments of the Pretoria Saltpan, 1999, Council of Geosciences; Pretoria, South Africa, 167-171.

Meyers P.A., Organic geochemical proxies of paleoceanographic, paleolimnologic, and paleoclimatic processes, Org. Geochem 27, 1997, 213-250.

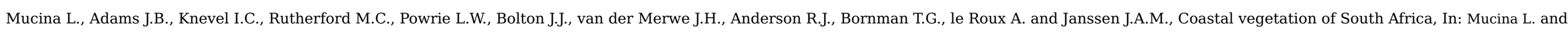

Rutherford M.C., (Eds.), The Vegetation of South Africa, Lesotho and Swaziland, 2006, South African National Biodiversity Institute; Pretoria, 658-696.

Neumann F.H., Scott L., Bousman C.B. and van As L., A Holocene sequence of vegetation change at Lake Eteza, coastal KwaZulu-Natal, South Africa, Rev. Palaeobot. Palynol. 162, $2010,39-53$.

Partridge T.C., Were Heinrich events forced from the southern hemisphere?, S. Afr. J. Sci. 98, 2002, 43-46.

Paruelo J.M. and Lauenroth W.K., Relative abundance of plant functional types in grasslands and shrublands of North America, Ecol. Appl. 6, 1996, $1212-1224$.

Paruelo J.M., Jobbagy E.G., Sala O.E., Lauenroth W.K. and Burke I.C., Functional and structural convergence of temperate grassland and shrubland ecosystems, Ecol. Appl. 8, $1998,194-206$.

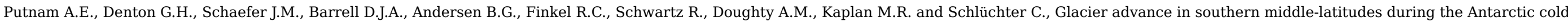
reversal, Nat. Geosci. 3 (10), 2010, 700-704.

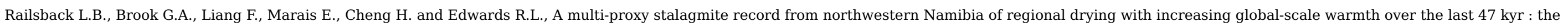
interplay of a globally shifting ITCZ with regional currents, winds, and rainfall, Palaeogeogr. Palaeoclimatol. Palaeoecol. 461, 2016, $109-121$.

Reason C.J.C. and Mulenga H., Relationships between South African rainfall and SST anomalies in the southwest Indian ocean, Int. J. Climatol. 19, 1999, 1651-1673.

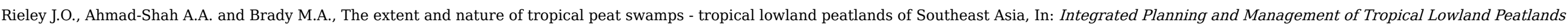
Workshop - Tropical Lowland Peatlands of Southeast Asia, 1996.

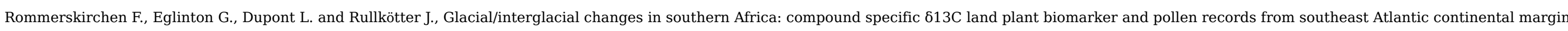
sediments, Geochem. Geophys. Geosyst. 7 (8), 2006, 1-21.

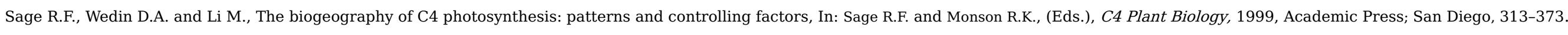

Schefuß E., Schouten S., Jansen J.H.F. and Damste J.S.S., African vegetation controlled by tropical sea surface temperatures in the mid-Plesistocene period, Nature 422, 2003, 418-421.

Schefuß E., Kuhlmann H., Mollenhauer G., Prange M. and Pätzold J., Forcing of wet phases in southeast Africa over the past 17,000 years, Nature 480, 2011 , 509-512.

Schmittner A., Saenko O.A. and Weaver A.J., Coupling of the hemispheres in observations and simulations of glacial climate change, Quat. Sci. Rev. 22 (5-7), $2003,659-671$.

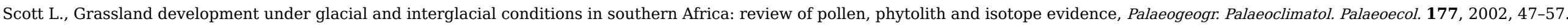

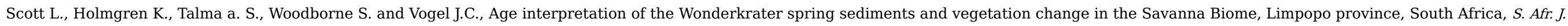
Sci. 99, 2003, 484-488.

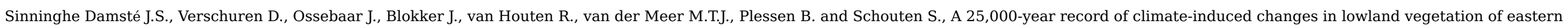
equatorial Africa revealed by the stable carbon-isotopic composition of fossil plant leaf waxes, Earth Planet. Sci. Lett. 302, 2011, 236-246.

Smuts W.J., Peatlands of the natal mire Complex - goemorphology \& characterization, S. Afr. J. Sci. 88, 1992, 474-483.

Stock W.D., Chuba D.K. and Verboom G.A., Distribution of South African C3 and C4 species of Cyperaceae in relation to climate and phylogeny, Austral Ecol. 29, 2004, 313-319.

Stocker T.F., The seesaw effect, Science 282, 1998, 61-62.

Stocker T.F. and Johnsen S.J., A minimum thermodynamic model for the bipolar seesaw, Paleoceanography 18 (4), 2003, 1-9. 
Talma A.S. and Vogel J.C., Late quaternary paleotemperatures derived from a speleothem from Cango caves, Cape province, South Africa, Quat. Res. 37, 1992 , 203-213.

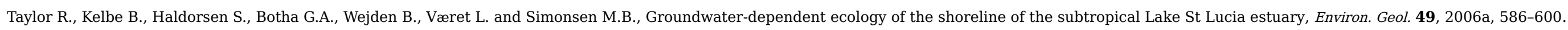

Taylor R., Adams J.B. and Haldorsen S., Primary habitats of the St Lucia Estuarine System, South Africa, and their responses to mouth management, Afr. J. Aquat. Sci. 31, $2006 \mathrm{~b}, 31-41$.

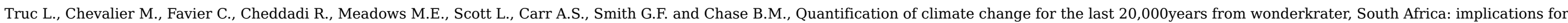
the long-term dynamics of the intertropical convergence zone, Palaeogeogr. Palaeoclimatol. Palaeoecol. 386, 2013, 575-587.

Tyson P.D. and Preston-Whyte R.A., The Weather and Climate of Southern Africa, second ed., 2000, Oxford University Press Incorporated; Cape Town, South Africa.

Vogel J.C., Fuls A. and Ellis R.P., The geographical distribution of Kranz grasses in South Africa, S. Afr. J. Sci. 58, 1978, 373-377.

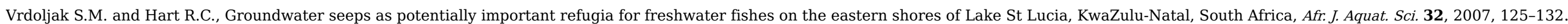

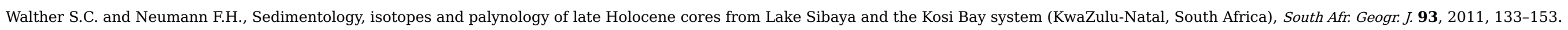

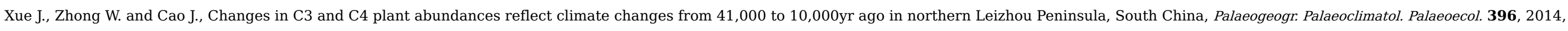
173-182.

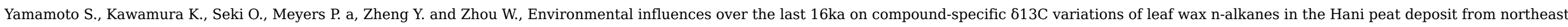
China, Chem. Geol. 277, 2010, 261-268.

\section{Highlights}

- Mfabeni peatland rare c. $47 \mathrm{kcal}$ yr BP old continuous palaeoenvironment archive.

- Bulk C isotopes represents proportional inputs of C3 and C4 terrestrial plants.

- Several climate events since Late Pleistocene chronicled in the peatland archive.

- Shorter climate events signal absent due to local hydrological overprinting.

- General anti-phase trend with Northern Hemisphere climate events.

\section{Queries and Answers}

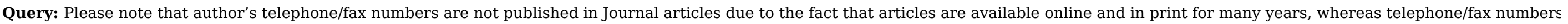
are changeable and therefore not reliable in the long term.

Answer: Fine.

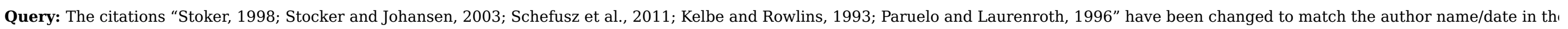
reference list. Please check.

Answer: All seams in order.

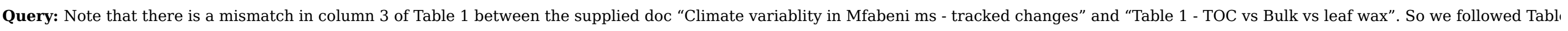
1 - TOC vs Bulk vs leaf wax. kindly check and amend if necessary. 


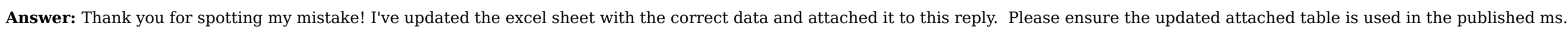

Query: Please confirm that given names and surnames have been identified correctly

Answer: Yes

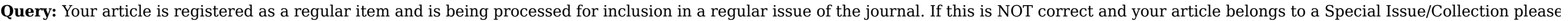
contact d.barrett@elsevier.com immediately prior to returning your corrections.

Answer: Yes 